\title{
Whatever happened to sin? An examination of the word and concept in contemporary popular culture
}

\author{
Hilary Brand
}

HILARY BRAND is a freelance writer and photographer, and author of several Christian books, including five Lent courses for Darton, Longman \& Todd. She has recently completed an MA in Theology, Imagination and Culture at Sarum College.

brand@btinternet.com

Nutfield, Surrey

The concept of 'sin' is rarely expressed in today's popular culture. When the word does appear it is frequently in ironic quotation marks and often used in terms of 'naughty but nice', minor misdemeanours, something disapproved of, an outmoded Catholic shame culture, Islamic oppression or fundamentalist extremism. Rarely is it used in the way the Church understands it. By analysing the use of the word in recent news reports and examining its use and absence across the range of twenty-first-century media, this study draws some conclusions about how UK secular society understands the word. It then goes on to explore how some twentieth-century cultural changes have impacted on its understanding, and concludes with some observations on how twenty-firstcentury Western culture still senses the underlying problem and yearns for a way to express it.

SIN • EVIL • POPULAR CULTURE • SEXUAL REVOLUTION • FRANCIS SPUFFORD 


\section{Outdated concept, residual usage}

My curiosity on this subject was first kindled when I read a quote from Paul Flowers, disgraced Chairman of the Co-op bank, who claimed that sin was an 'old-fashioned term, which I rarely use'. Given that Flowers was also a Methodist minister and had been accused of financial mismanagement, coke-sniffing and using rent boys, it seemed perhaps a term he should embrace. (To be fair, the statement, which came in response to Jeremy Paxman's Newsnight question, 'Do you think you've sinned?', was followed by a rather weak acknowledgement: 'Of course I have. I'm in company with every other human being for having my frailties and some of my fragility exposed.' ${ }^{1}$ )

My interest was further aroused by Paul Vallely in an article in Third Way magazine, where he reported that in a conference bringing US news commentators together with top religious figures, the question 'Whatever became of sin?' was a hot topic. An academic started the conversation: Google it, he said, and you'll find most mentions nowadays are metaphorical or frivolous. The concept of sin has decayed in meaning in US culture, he said. It's true in the UK too, where the media are most likely to use it in connection with the eating of cream cakes. ${ }^{2}$

But it was when I read Francis Spufford's book Unapologetic that the idea began to form. I had been surprised to find a book about Christian faith being suggested as a Sunday Times best read and published by Faber and Faber, not a usual stalwart of the Christian bookshops. In Spufford's book, a witty personal defence of faith subtitled Why Christianity Still Makes Surprising Emotional Sense, the 'sin' word is almost entirely absent. Spufford replaces it with a curious acronym: the 'HPtFTu', which, being translated, means 'the Human Propensity to Fuck Things up' ${ }^{3}$ Spufford's rationale for his alternative term is clear:

One of the major obstacles to communicating what belief feels like is that I'm not working with a blank slate. Our culture is smudged over with half-legible religious scribbling. The vocabulary that is used to describe religious emotions hasn't gone away, or sunk into an obscurity from which you could carefully reintroduce it, giving a little explanation as each unfamiliar new/old term emerged. Instead it's still in circulation, but repurposed, with new meanings generated by new usages; meanings that make people think they know what believers are talking about when they really, really don't. 
Case in point: the word 'sin', that well-known contemporary brand name for ice cream. And high-end chocolate truffles. And lingerie in which the colour red predominates ... ${ }^{4}$

So, is the word 'sin' outdated? Does it have no more than ironic usage in twentyfirst-century popular parlance? It is this question that forms the basis of this article.

\section{An initial approach}

I am not the first person to address these questions in the twenty-first century: Hugh Connolly (2002), Gary Anderson (2009), Jason Mahn (2011), Derek Nelson (2011) and Paula Fredriksen (2012) have all found reason to explore the issue. Each of these, however, has begun with history and theology and rarely delved further into the thought processes of today's postmodern secular Western society. I decided to start the other way round, beginning in the twenty-first century and where necessary working backwards, to establish how the s-word got where it is today.

I began by trawling through newspaper references to the word 'sin' and attempting some analysis of where and how they appear. Although I looked at many articles and news items with some connection to 'sin' published over the last few years, I thought a more systematic approach was also needed. Therefore, using the database Newsstand and selecting at random a 16-day period, 2-17 March 2015, I made an analysis of all uses of the word. ${ }^{5}$ The search covered all national and local newspapers in the UK and Eire, which are the parameters of Newsstand, and produced a working total of 527 articles.

My initial discovery was that to find the word used in contemporary media you must turn first to the sports pages, where half of all entries were found in the use of the term 'sin bin'. For the uninitiated, like me, this refers to the penalty box used in rugby (and ice hockey) where any player engaging in dangerous play is sent to sit out for a period of the game. During this time the player is not replaced, so there is an element of letting the side down. The term occasionally transfers over into more general usage, such as the suggestion reported in several papers that MPs in the House of Commons should be sent to a'sin bin' for barracking opponents: 'Bring on the sin bin for MPs whose noise betrays contempt.'

The word 'sin' has also found a place in contemporary financial usage with the use of the term 'sin stock' for investments in tobacco, alcohol and defence, and 
'sin taxes' for levies on alcohol, tobacco and, potentially, sugar. This latter example highlights a problem of my analysis, as I tried to discern whether the word was being used seriously, or ironically of mild wrongdoing ('the worst sin of all, changing the recipe and taste of what was the best chocolate in the world' $;{ }^{\prime}$ 'I am about to commit the ultimate mummy sin and buy my toddler's birthday cake $\left.^{\prime 8}\right)$, or more trivially of anything provoking disapproval of some kind (Amsterdam, 'notorious as a city of legalised $\sin ; ;{ }^{\prime}$ 'ScottishPower's sin was to fail to correct serious fault lines' ${ }^{\prime 10}$ ). As might be imagined, the borders are porous, but there were certainly far more examples on the ironic, trivial side (111) than were to be found of truly serious usage (53).

Within the former, there were several examples that touched on selfindulgence in one form or another ('the cardinal British sin, talking about yourself'; 11 'Coconut milk ... too many sins'; ${ }^{12}$ 'middle-class men who sin abroad and feel bad' $^{\prime 13}$ ). There were, however, less incidences than might have been imagined from Vallely's and Spufford's comments.

Spufford is entirely right, though, in his comment that the word is still in wide circulation, albeit as 'half-legible religious scribbling', an observation evidenced by the number of 'sin' figures of speech still in common usage. ${ }^{14}$ The terms'sins of the fathers' and 'seven deadly sins' were very frequent, with 29 entries each. ${ }^{15}$ The next term most frequently employed was 'cardinal $\sin$ ' (15 entries), having entirely lost its Catholic use as a mortal sin, in favour of 'an unforgivable error or misjudgement'16 ('Help, I've committed a cardinal sin. I've fallen in love with my flat mate 17 ). Biblical echoes still occur with 'sins of omission' and ' a multitude of sins' ('perfect for covering a multitude of sins and giving you a long, lean silhouette'18) having seven entries each, and 'atonement for sin' and 'be sure your sins will find you out' also making appearances. Other terms include 'miserable as sin', 'guilty as sin' and 'for my sins', this last being always a jokey suggestion of punishment.

But what of more serious uses of the word? For its use in an intentional Christian religious context, one has to turn to those smaller local papers that occasionally include a column from the local vicar or a letter from some strident believer. Other than that, reports of religious statements were generally tinged with editorial scepticism, as of the bishop who felt gay people should not be parents, ${ }^{19}$ and the preacher convinced Fifty Shades of Grey would lead to sex crime; ${ }^{20}$ if not with downright disapproval, as of a Christian nursery worker sacked for'telling a lesbian colleague her lifestyle was a sin'.21 Beyond that, the only Christian statement getting reasonably respectful coverage came from 
the Pope, whose statement that 'Abandoning the elderly is a mortal $\sin ^{\prime 22}$ was widely quoted.

In national papers, 'sin' linked to religion was far more prevalent in an Islamic context (nine entries) than a Christian one. Examples include the British-born jihadi who craved martyrdom, asking 'When will Allah pick me? It must be my $\operatorname{sins}^{\prime 23}$ and Boko Haram's repeated slogan that 'Western education is a sin.24

But what are the activities that the secular UK media seriously consider to be 'sin'? On the evidence of this sample, the most prevalent were racism (six entries) and financial misconduct (five), though suicide, murder, pornography and envy were also mentioned.

To sum up, however, it seems that Boyd Tonkin's comment, that 'the audience will always root for warm-blooded sin over cold-hearted sanctity,' an apt assessment of UK newspaper attitudes.

\section{What about evil?}

To provide some comparison, I also examined uses of the word 'evil' over the same period. First to be noted is that 'evil', with 805 entries, gets a bigger press than 'sin'. From this total, 287 related to fiction: film, TV and theatre drama, novels and computer games ('evil villains', the battle between good and evil). Another 105 referred to brutal crime; while other activities include the condemnation of gay people (9), dog poisoning at Crufts (5) and cruel tweets (4). There were, of course, a fair number of ironic references (the Tories, José Mourinho, capitalism, FIFA) and more trivial ones (sugar, motorists as seen by cyclists, calories, the fashion industry). The incidences of a Friday 13th and a partial eclipse brought a rash of articles on superstition and evil spirits (33), and the Christian religious context was again mainly limited to local papers. ${ }^{26}$

It is noticeable that 205 mentions referred to what could be described as structural rather than personal evils: governments, ideologies, institutions, companies, etc. By far the highest of these with 105 mentions was Islam and Islamic terrorism. ${ }^{27}$ The next highest ideology treated as a serious evil was Nazism, with 11 entries. Commercial institutions producing and promoting drugs and tobacco got six entries each, while oppressive political regimes in other countries - Russia, China and North Korea - were also mentioned.

However, at the end of all this, what is for me the most interesting statistic is the number of times that 'evil' and 'sin' appear in the same article: a mere 15 times over the same period. ${ }^{28}$ Of these, apart from three religious articles in 
local papers, only six were serious: two on Catholicism, two on tobacco 'sin stocks', one on Boko Haram, and one historical reference to the slave railroad. It is to be noted that all these six refer to institutions. ${ }^{29}$

The only use of the word 'evil' in relation to ordinary British people was a report of a crowd of onlookers gawping at a suicidal man threatening to jump from a tall building. Some jeered, telling him to 'Go on, jump', while others took selfies. The man eventually jumped to his death. ${ }^{30}$ No one, however, referred to these callous public reactions as 'sin'.

In summary, this analysis highlights a notable difference between the popular usage of 'sin' and 'evil'. Sin, if used at all seriously, refers predominantly to individual cases of personal, and sometimes private, misdemeanour. By contrast, evil is something done by 'the other': terrorists, murderers, Nazis, or those in political or commercial power. Evil's prevalence as a term rather than 'sin' arguably indicates a tendency to divert responsibility for the world's wrongs away from ordinary individuals, and locate it in less personal organisations and systems. The use of 'evil' and the trivialising of the term 'sin' threatens to replace an understanding of responsibility for the cumulative effect of many small wrongs with a desire for scapegoating.

\section{Which way now?}

Having gained some understanding from this overview of the newspapers, it became clear that understanding the contemporary usage of sin was a potentially massive agenda. I now wanted to incorporate as many references as possible to relevant contemporary popular culture. So, to limit the scope, just two main areas of focus are included in this paper: the first looks at the tone of irony which suffuses so much of contemporary Western culture and at the pursuit of pleasure which very often underlies it; the second deals with sex, the dismissal of 'sin' as a term for any consenting adult activity, and the fury at institutional abuse. Out of these foci it will be possible to note the way the term 'sin' has slipped in contemporary usage, and give some initial pointers about whether it ought to be recovered by the Church.

\section{Ironic tone, indulgent trivia}

\section{A tale of two movies}

Perhaps as good a way as any to begin to chart the overwhelming presence of irony in Western culture is a comparison between two films, both released in 
the UK in the summer of 2014, but arriving with us from outside and within Western culture respectively: A Touch of Sin by Chinese director Jia Zhangke, and Sin City 2: A Dame to Kill For, inspired by the comic books of Frank Miller.

A Touch of Sin follows four stories of violence, each based on a recent real-life case and each provoked by frustration with the widening gulf between rich and poor in contemporary China. It is an angry condemnation of capitalist injustice, painting 'a poisonous picture of people pushed beyond the boundaries of civilised behaviour by the sickness of the circumstances in which they live.'.31 The film ends with one of the protagonists encountering a performance of traditional Chinese theatre. A voice repeatedly sings, 'Do you understand your $\sin ?^{\prime 32}$ A close-up of the woman, who has killed defending herself from a rich attacker, shows she does indeed understand, but the film ends with a wide shot of the audience of Chinese townspeople looking blank and untouched. Jia Zhangke's impassioned attempt to make his compatriots understand was thwarted: the film was denied release in mainland China. ${ }^{33}$ The film's ultra-violence was inspired, says the director, by'morally infected westerns and martial arts movies.' Nevertheless, he claims, 'I don't admire or worship violence. To fight violence with violence is a tragedy. This film seeks the roots of violence. ${ }^{34}$

In contrast, Sin City: A Dame to Kill For is a triumph of style over substance, delighting in violence in an entirely passionless way. The film shows its comicbook roots in slick dark monochrome with occasional splashes of lurid colour - most often blood. It is always night-time in this anonymous retro-future city, the 'dames' are always scantily clad, both sex objects and female warriors, and men and women wield an impressive array of guns and other weaponry, slaughtering innocents and villains alike. All is ironic and tongue-in-cheek, but occasional snatches of dialogue express a deep underlying despair:

'Saturday night. Me and all the other suckers, sucking up the juice. I get that way sometimes: empty in the gut, hollow in that lonely place and wishing I had an excuse to break somebody's face. It was just another Saturday night.'

'This place stinks. I never used to notice - not when I danced. Now I smell everything ... I know exactly where I am. I know exactly what I am.'

'This rotten town. What it can't corrupt, it soils ... It soils everybody.'35 
Both films have the word 'sin' in the title, both portray horrific violence, and both explore the theme of 'city'. Sin City makes clear that it is the city itself that corrodes and corrupts. A Touch of Sin vividly depicts the dehumanising effects of rapidly increasing urban sprawl. However, the similarity between the two films ends there. While the Chinese film has an urgent moral message, its amoral and world-weary Hollywood counterpart says nothing, albeit very stylishly. It is an exercise in ironic counterpoint with a surface gloss that entirely negates any horror in what it portrays. While one is motivated by righteous anger, the other seems motivated only by pushing aesthetic boundaries, cynically exploiting the taste for violence to rack up profits. Sin, as we noted above, has lost its responsibility in Western culture.

But now let us look at one particular city, and then move on to consider the indulgence and fantasy it epitomises.

\section{Viva Las Vegas}

My wider trawl through newspaper articles brought up many on Las Vegas mainly for boxing bouts, star performances and starlet walkabouts - and in every case it was known at some point by its alter ego of Sin City. That is curious, because what epitomises Vegas these days is not vice, gangsters and drugs, but a giant simulacrum devoted to fantasy and sensory indulgence: an hourly erupting volcano, a first-floor Grand Canal, a never-ending circus show. Even its dark underbelly of gambling is rarely now enacted in the live drama of the gaming tables, rather it is the 'slots': the deadening lone interaction with a machine. It is, to use Umberto Eco's term, an 'apex of hyperreality.' ${ }^{36}$ As Jean Baudrillard suggests, such manifestations of the hyperreal mask the fact that there is no longer an underlying reality: 'It is truth that hides the fact that there is none. ${ }^{37}$ There is no'real life' outside - the simulacrum has become more real than that which it seeks to portray: 'It is no longer a question of imitation, nor duplication, nor even parody. It is a question of substituting the signs of the real for the real.' 38

Does this suggest that when, as we frequently do, we find the s-word used as a metaphor for some sensory indulgence, it may be completely devoid of any assumption of a real underlying condition?

In answer, let us look at some of the products that this hyperreal metaphor has been used to promote. You can buy Sinful women's clothing, a range of rather ordinary tee-shirts and sweatshirts, emblazoned with 'Sinful' across the chest; or Sinner sunglasses, whose website proclaims 'Follow your dreams just like we 
do.39 And then there are Sinful Colors nail varnishes:'Colour you crave at a price you love'; ${ }^{\prime 0}$ or So Sinful body spray: 'Fragrance with attitude.' ${ }^{\prime 1}$ If you want a night out thus adorned, you could go to a Sin City Blues dance class in London: 'Feel the pulse, move to the music'; ${ }^{42}$ or hop over to Paris to the Hotel Vice Versa where each room is styled to the theme of one of the seven deadly sins:'I wish you happy sins for sweet nights. ${ }^{\prime 3}$ If you want an evening in, then you may choose to play Divinity - Original Sin video game: 'Original Sin forces you to confront the consequences of your actions'; ${ }^{44}$ or Sin and Punishment - Successor of the Skies: 'Gameplay is straightforward, basically kill anything that moves.' 45

Then, of course, there is indulgence of the taste buds. In 2003 Magnum famously launched a range of Seven Deadly Sins ice creams, under the slogan 'Give in to it.' 'Greed' was tiramisu, 'Jealousy' was pistachio, 'Lust' was strawberry, and so on. All, of course, contained chocolate. Marketing Magazine reported:'The UK creative strategy for Magnum targets successful, empowered women, by suggesting that "sinning" is not a negative, but a means of indulging themselves. ${ }^{46}$

The marketing for GU Puds, while it does not use the s-word, adorns each packaged dessert with a series of slogans aimed at the same effect: 'Pleasure is everything. Give in to happiness. Reject propriety, embrace variety. Prudence is sooo 1658. Life is fleeting; clasp it with both hands. Seek delight. Trust your impulses. Ordinary is pointless. Break free. All hail the GU decadents.' ${ }^{\prime 7}$ This sort of marketing is directly pitched against the fear of calories and the shame of gaining weight, and is a subtle game. The Slimming World organisation strangely used the word 'Syn' and created an online calculator system to work out which of these 'enjoyable little extras' could be allowed. ${ }^{48}$ Actual obesity might well be sinful in a Christian sense, being usually linked directly to gluttony and damage to health. However, when a size 8 lingerie model seen buying a cake draws the comment 'No sin goes unpunished', with the suggestion that she will need to spend the rest of the day working out, ${ }^{49}$ then the calorific taboo is being misused - potentially dangerously so.

The sense of food transgression need not be related to calories, however; another aspect is the breaking of a taboo as expressed by the Jewish author Howard Jacobson on his pleasure in a bacon sandwich: 'Whenever I eat one I feel the very, very sweet, ecstatic consciousness of sin and the brown sauce makes it positively orgasmic.'50

There are several elements at work in Jacobson's use of the s-word here. Irony, of course, since contemporary reason tells us there is no real damage likely to be caused by eating pork. It also signifies defiance, a pride and gleefulness in 
the rejection not just of a social norm or a parental prohibition, but also of an outmoded religious code, and ultimately God. Beyond that is the clear suggestion that it is not just the taste of bacon that provides the pleasure, but the very act of taboo-breaking. The 'very, very sweet ecstatic' state, coupled with the'orgasmic' brown sauce, give the act of eating a sexual frisson and with it perhaps a faint reminder that the ancient taboo is based around a sense of uncleanness and defilement.

\section{The pleasure principle and beyond}

Jacobson's ecstasy-inducing sandwich brings to mind the term 'jouissance'. Coined by the postmodern psychoanalyst Jaques Lacan, its nearest English translation, 'enjoyment', fails to communicate the dark edge which the French word conveys. Using Freud's definition of the 'pleasure principle' as the instinctual seeking of pleasure and avoidance of pain, Lacan suggests that 'jouissance' is a more irrational seeking of pleasure, which may lead on to pain, related to 'transgressive violations, the breaching of boundaries and breaking of barriers.'51

This is a very different view from that of Paul Ricoeur, who makes clear the difference between the 'finitude of pleasure' and the infinitude of 'happiness', which latter he describes as 'the perfection of the total work of man ... the termination of a destiny ... the fullness of ... beatitude'. For Ricoeur, the temporary satisfaction of pleasure, which as something rooted in finitude, is necessarily flawed and fallible, has eclipsed the 'perfection of pleasure' found in true happiness. Drastic action is needed:'A certain suspension of pleasure is necessary for the radical significance of happiness to be made clear and for pleasure itself to be reaffirmed. ${ }^{\prime 2}$

But the twenty-first-century Western zeitgeist is, as yet, unlikely to turn to suspension of pleasure. Credos of psychological hedonism - that pleasure or pain are the only things to motivate us - and ethical hedonism - that only pleasure has value - inevitably predominate in our consumerist landscape. Propelled by capitalism, fuelled by advertising, facilitated by a massive media machine, the drive for ever-increasing indulgence has arguably never been stronger and the s-word has been harnessed as part of this consumerist drive. Far from being something from which to flee, sin is seen here as something worth flirting with, perhaps even desiring. 'Sin' is ironic. Despite this, though, does the ironic and often deliberately cynical use of the word still carry echoes of an earlier and deeper meaning? Perhaps we have discovered our first pointer for the recovery of the concept in the Church. 


\section{Sexual transition, moral revision}

Nowhere, it seems, is the 'sin' word more contended than in the sexual arena. The availability of birth control and the need for population limitation has irrevocably separated sex from procreation in the Western world, and an underlying philosophical drive towards personal freedom has abolished a whole raft of taboos: primarily sex outside marriage and same-sex relationships.

Writing in 1966, Paul Ricoeur seemed to imply that sexuality would not be the future battleground for ethics:

It is not from meditation on sexuality that a refinement of the consciousness of fault will be able to proceed, but from the nonsexual sphere of existence: from human relations created by work, appropriation, politics. ${ }^{53}$

Ricoeur must have been aware of the 'sexual revolution' of the 1960s, but perhaps he underestimated how much further it had to run. Nearly fifty years on, issues of sexuality are still proving to be a major field of conflict, at least within the Church. It remains to be seen, however, whether our preoccupation with this arena leads to the 'refinement of the consciousness of fault' that Ricoeur desired.

\section{Obsolete taboo, unnatural disapproval}

The underlying morality of sex had, of course, begun to shift very much earlier than the 'swinging 60s'. Writing in the 1970s, the psychiatrist Karl Menninger asked the same question as this paper in his book Whatever Became of Sin? He came up with a surprising answer. It was all down to masturbation:

The amazing circumstance is that some time after the turn of the present century, this ancient taboo, for the violation of which millions had been punished, threatened, condemned, intimidated and made hypocritical and cynical - a taboo thousands of years old - vanished almost overnight! ... It is not difficult to see why ALL sin other than 'crime' seemed to many to have disappeared along with this one. ${ }^{54}$ 
Whether the change was quite as instant as Menninger claims is arguable, but certainly nowadays no one believes the rumours of blindness, hairy hands and stunted growth. Even the Catholic Church has toned down much of its previous rhetoric against masturbation, while still teaching that it is 'an intrinsically and seriously disordered act'. ${ }^{55}$ But in describing the changed views of Western society at large, Menninger is surely right that 'the great phenomenon of a deadly sin suddenly disappearing ... without anyone noticing it, affected our attitude to other disapproved behaviour. ${ }^{56}$

Curiously, though, masturbation is still a taboo subject, or at least it is in serious contexts. It is a different matter when it comes to humour, where it has become the source of numerous jokes: famously, there is Cameron Diaz's hair gel in There's Something about Mary (1998), and the incident on the Peep Show where the only thing Jeremy can find to arouse his fantasies at a sperm bank is the image of the Queen on a $£ 20$ note. ${ }^{57}$ It is now even acceptable to joke about female masturbation. ${ }^{58}$ In Gavin and Stacey, for example, Nessa borrows some AA batteries for 'a bit of me-time' and Stacey comments, 'I had three just watching Cash in the Attic. ${ }^{159}$

In the internet era, however, with ever-available and increasingly extreme pornography exploitatively using women and children for arousal, and with sex addiction reported as massively on the increase, perhaps masturbation should again be taken seriously. ${ }^{60}$

But beyond the harm done by the practice itself is another danger. Masturbation's status in moral discourse (or perhaps, its lack of status) is a telling indicator of the contemporary attitude towards 'sin' in general. When society sweeps away a taboo such as this, the whole concept of sin is discredited. As John Portmann remarks, referring to masturbation, alongside birth control and loss of virginity: 'Since so few people believe in them any more, these over-the-hill sins risk ruining the reputation of other, genuinely dangerous sins. ${ }^{61}$

\section{Lost reputation, beleaguered institution}

It is not only the sins, however, that risk losing their reputation in today's culture, but also the Church itself. Here I will focus primarily on the Roman Catholic Church, because it has been such a target for contemporary media, as an authority structure discredited and in disarray. To serve as examples, let us look at two recent films. 
The movie Calvary, released in 2014, has one of the most original openings in cinema. In the confessional, an unseen parishioner tells the priest, 'I first tasted semen when I was seven years old.'

'That's certainly a startling opening line,' replies Father James, and the man goes on to explain that he was raped by a priest, orally and anally, for five years. He states that in revenge for this crime he is going to kill Father James in one week's time.

There'd be no point in killing a bad priest. But killing a good one, that'd be a shock, wouldn't it. I'm going to kill you, Father ... because you've done nothing wrong. I'm going to kill you because you're innocent.

Thus the film's premise is set up and it takes us through the week leading to Father James' personal Calvary. Every parishioner seems to have some dark secret to hide, and the laconic priest accepts them all, not without challenge, but certainly without blame: 'I think there's too much talk about sins, to be honest ... I think forgiveness has been highly under-rated.' Despite his matter-of-fact kindness, his parishioners are cynical. One comments behind his back: 'Good man, fine man, makes you wonder what he's hiding.' The most telling moment comes when the priest catches up with a little girl walking alone down a country lane. He chats quietly, walking alongside her, until the girl's father drives up and angrily gathers up the child, his silent fury indicating the assumption that a priest alone with a child must be contemplating paedophilia.

The priest keeps his appointment at the beach and meets his death, taking upon himself the sins of the Church of which he is part. ${ }^{62}$ The film interestingly explores the true biblical concept of the scapegoat, in which the innocent creature has the sins of the whole community it represents loaded on to it. Sins and scapegoats are perhaps never far from one another.

It is no surprise that Calvary was set in Ireland, where in 2009 the Ryan Report exposed 'endemic' physical and sexual abuse in church-run schools and orphanages: 800 alleged abusers in more than 200 institutions during a period of 35 years. ${ }^{63}$

In a recent TV series entitled Sex and the Church, Diarmaid MacCullough described how in recent years country after country has uncovered stories of priests abusing those in their care. It was not only a problem in Catholicism, he 
conceded, but added: 'Catholics have gone much further in trying to conceal it. Successive popes and bishops have been more worried about protecting the Church from scandal. The Church depends on trust. In thousands of cases it has forfeited that trust. ${ }^{64}$

Another recent movie, also set in Ireland and based on a true story, told of a different aspect of abuse. Philomena tells of a woman whose illegitimate son was taken from her without warning by the nuns with whom as a teenager she received shelter. Her quest to find him, aided by the journalist Martin Sixsmith, leads eventually back to the old mother and baby home where they discover the son's ashes buried in the adjoining graveyard. Philomena is determined to forgive, but Sixsmith is incensed that this information had been withheld from her. The following snatch of dialogue encapsulates reactions both inside the Church and out:

Sister: 'Those girls have nobody to blame but themselves and their carnal incontinence. What do you expect me to do about it now?'

Sixsmith: 'I tell you what you could do. Say Sorry. Apologise. Stop trying to cover things up. Get out there and clear all the weeds and crap off the graves of the mothers and babies who died in childbirth.'

Sister: 'Their suffering was atonement for their sins.'

Sixsmith: 'One of those mothers was 14 years old!'

Sister: 'The Lord Jesus Christ will be my judge, not the likes of you.'

Sixsmith: 'Really? I think if Jesus was here now, he'd tip you out of that fucking wheelchair and you wouldn't get up and walk.'65

Sin and atonement are closely linked here; in this case the Sister's response showed she felt the mothers and babies were experiencing atonement, while Sixsmith's response indicates he felt they were being scapegoated. This difference of perspective highlights the contemporary uncertainty over where to locate and how to describe personal responsibility, which is thus a contributing factor to the slippage of the usage of the s-word.

In April 2014 Pope Francis did show himself willing to apologise, taking responsibility for child sex abuse by clergy and asking forgiveness for the damage caused. He committed the Catholic Church to stronger action on child 
protection and tougher penalties to offenders. ${ }^{66}$ But despite the Pope's best efforts the Catholic Church has a long way to go to regain trust and respect. Perhaps popular reaction to Catholic scandals can best be summed up by graffiti artist Banksy, who in 2011 made a sculpture entitled Cardinal Sin. The work featured a replica stone bust of a cardinal with the face sawn off and replaced by mosaic bathroom tiles to give a pixelated effect. Banksy commented, 'At this time of year [Christmas] it's easy to forget the true meaning of Christianity - the lies, the corruption, the abuse. ${ }^{67}$

Abuse issues are at least clear-cut. No one doubts that such institutional corruption deserves the label 'sin'. It stands in its own category of wrongdoing, more to do with power and control than lust per se, while also pointing up the dangers of repression inherent in celibacy. When it comes to sexual activity by consenting adults, however, it is a different issue. In official Catholic Church documents, the term 'living in sin' continues to be used for those in any sexual relationships outside marriage (including remarried divorcees), and the Church officially bans such people from receiving communion. Pope Francis, who is forthright and frequent in his use of the s-word, has largely avoided the term in reference to sexual matters and is working hard to loosen attitudes. In March 2015 an old family friend of the Pope leaked the news that the pontiff had privately told a divorced woman 'living in $\sin ^{\prime}$ that she could receive Holy Communion. The Vatican did not deny the news but said that 'if' the Pope had these conversations they were private and did not have any bearing on the teaching of the Church. ${ }^{68}$

All the while, as the institution resists change, its attitude to sex is frequently derided by outsiders, particularly those who were previously inside. The once logical connections between sin, atonement and salvation have been turned inside out as the Church's stance is considered utterly untenable. Pop diva Madonna, who has a long history of shock tactics using religious iconography, illustrated this recently with her song 'Holy Water', released in March 2015:

I can let you in heaven's door

I promise you it's not a sin

Find salvation deep within

We can do it here on the floor. ${ }^{69}$

In these lyrics what was once considered 'sin' now becomes salvation, and Madonna takes it upon herself to provide a priestly absolution. 
In 2014, a newer and more thoughtful artist, Irish rock musician Hozier, had a hit single with a related message in 'Take Me to Church'. Against a video depicting gay intimacy, the lyrics claim, 'There is no sweeter innocence than our gentle sin.'The Church he describes, however, is harsh and unforgiving:

Every Sunday's getting more bleak

A fresh poison every week...

Take me to church

I'll worship like a dog at the shrine of your lies

I'll tell you my sins so you can sharpen your knife. ${ }^{70}$

In an interview, Hozier explained how the song grew out of his childhood frustration with his church background: 'Growing up, I always saw the hypocrisy of the Catholic Church. The history speaks for itself and I grew incredibly frustrated and angry. ${ }^{\prime 1}$ In another interview, he elaborated further:

[T] he church through its doctrine would undermine humanity by successfully teaching shame about sexual orientation ... There is still that kind of public relations tactical retreat of saying 'We love the sinner but we hate the sin'. It's a backhanded way of telling someone to be ashamed of who they are and what they do. ${ }^{72}$

\section{Vocal protest, quiet retreat}

The use of the word 'sin' to engender a sense of shame is also recognised by the other end of the theological spectrum; for instance, Micah J. Murray, an evangelical media commentator, says:

I'm done. I can't look my gay brother in the eye anymore and say 'I love the sinner but hate the $\sin ^{\prime} \ldots$ Despite my theological disclaimers about how I'm just as much a sinner too, it's not the same. We don't use that phrase for everybody else. Only them. Only 'the gays'... It's a special sort of condescending love we've reserved for the gay community. ${ }^{73}$

The application of the word 'sin' to homosexual activity brings the issues surrounding the term into sharp relief. It seems that no use of the word 'sin' provokes as much rage, both considered and irrational, as when applied to homosexuals, as these news items demonstrate: 
A born-again Christian nursery worker ... was fired for gross misconduct after telling a lesbian colleague her lifestyle was a $\sin .^{74}$

Singer Ariana Grande turned to the Kabbalah faith after her homosexual brother was rejected by the Catholic faith. 'When my brother was told God didn't love him, I was like, "OK, that's not cool" ... [The Church] said Spongebob Squarepants is gay and he's a sinner and should burn in hell ... ${ }^{75}$

Actress Lea DeLaria unleashed an expletive-filled rant at a Bible preacher on a New York subway train ... The exchange became more unpleasant when he mentioned the 'sin' of homosexuality. ${ }^{76}$

One of the reasons that the application of the s-word to homosexuality has brought it into such sharp contention is that, while 'love the sinner and hate the $\sin ^{\prime}$ is a regular mantra of the Church, it is difficult to separate identity and activity in the sexual arena. Homosexuality, as with all sexuality, not only describes certain behaviours, but also profoundly embraces someone's sense of identity, and so it is often felt that to call it 'sin' therefore implies a wholesale rejection of a person's humanity.

It is for this reason that there has in some quarters been a retreat from using the s-word in this context. So, for instance, evangelical leader Steve Chalke rocked the evangelical community in 2013 by taking a stand for gay marriage, refusing to treat gay people as 'pariahs' and 'blame them for who they are. ${ }^{\prime 77}$ Similarly, both Pope Francis and Archbishop of Canterbury Justin Welby have asked identical questions recently in relation to homosexuality: 'Who am I to judge?' The Pope asked it of reporters in 2013: 'If a person is gay and seeks God and has good will, who am I to judge? ${ }^{178} \mathrm{He}$ did, however, restate the Catholic position that homosexual acts were sinful, while orientation was not. The Archbishop's comment, at a question and answer session with sixth-formers in Highgate in 2012, went a little further:'I see my own selfishness and weakness and think "Who am I to judge them for their sins?", if they have sins [my emphasis]. We shouldn't demonise and dismiss and hate each other as that is so dangerous. ${ }^{179}$

However, he too was careful to uphold his Church's position by reiterating opposition to gay marriage. These statements show a humility and compassion that must be applauded, but they do, of course, raise a rather large question. If the two senior church leaders of the Western world describe themselves as unqualified to judge, then who, if anyone, can evaluate what is sinful behaviour any more, and on what basis can they do it? 


\section{Silent avoidance, spiritual vacuum}

The danger of avoiding sin-talk in the sexual arena is that it easily leads to throwing out the concept of personal sin altogether. It can create a strange vacuum, as theologian Patrick Cheng discovered. In his book From Sin to Amazing Grace: Discovering the Queer Christ, Cheng explains how, after encountering religious rejection for his homosexuality, he eventually found acceptance in the Metropolitan Community Church of New York:

One of the things that puzzled me, however, was that sin or grace was rarely discussed from the pulpit. Yes, there was a condemnation of the evils of homophobia within religious and secular institutions. And yes, there was a condemnation of structural evils such as racism, sexism, poverty and violence. However there was little to no discussion about individual sins that separated us from God, our neighbours and our true selves. Nor was there any discussion of the amazing grace that made us whole... At best, I have found that $\mathrm{LGBT}^{80}$ Christians try not to think too much about the issues of $\sin$ and grace ... We convince ourselves that the doctrine of sin has outlived its usefulness and ... downplay or avoid the topic. ${ }^{81}$

While Cheng acknowledges that 'This silence is understandable because so many LGBT people have been deeply wounded by sin-talk', he points out that 'Ignoring the doctrines of sin and grace deprives us of the theological tools to describe the true state of the world'.82

\section{Continued need, renewed understanding}

\section{The yearning for change}

There are small signs that it is not only within the theological arena that there is a yearning for the language of sin.

One of the most highly applauded TV drama series of recent times is Breaking Bad, where mild-mannered chemistry teacher Walter White discovers he has cancer and, wanting to provide for his family, decides to cook up and sell crystal meth. It's a story about a good man becoming a monster, though it does so without recourse to prescriptive morality and certainly not the s-word. However, it certainly evokes it. 'Sin lives at the centre of this show,' wrote one journalist, ${ }^{83}$ while another commentator described it as demonstrating 'why 
society still needs sin language'.84 The show's creator, Vince Gilligan, has described Walt as being suffused with 'sin' and as someone who 'corrodes and ultimately destroys the healthy people round him'.'Maybe on some level what I'm intending is to explore a world where actions do have consequences, ${ }^{\prime 85}$ says Gilligan. 'I feel some sort of need for biblical atonement, or justice or something.'86

A similar sort of yearning is expressed by Katie Carr, a character in Nick Hornby's novel How to be Good. When she bumps into her depressed brother in church, an unlikely venue for both of them, he asks why she is there:

'I wanted to be forgiven.'

'For what?'

'For all the shitty things I do,' I say.

Mark [the brother] only just made my guilt-list, and when I look at him now that seems almost laughably complacent ...

'You don't do anything shitty.'

'Thank you, but I'm human. That's how humans spend their times, doing shitty things.' ${ }^{87}$

At an earlier point in the novel, Katie describes what drove her to the church:

When I look at my sins (and if I think they're sins, then they are sins), I can see the appeal of born-again Christianity. I suspect that it's not the Christianity that is so alluring, it's the rebirth. Because who wouldn't wish to start all over again? ${ }^{88}$

\section{The dilemma of language}

It is clear that the word 'sin' is in trouble. It is no longer common currency, or at least not in the way the Church has understood it for centuries. Moreover, use of the word is frequently dismissed as a bad thing in itself - though not everyone is quite so damning as Richard Dawkins, with his assertion that 'The Christian focus is overwhelmingly on $\sin \sin \sin \sin \sin \sin \sin \sin \sin \sin$. What a nasty little preoccupation to have in your life.'89

However you describe it, though, society continues to have a deep malaise, which needs to be diagnosed and named. While the word itself may be in trouble, an understanding of sin is indispensable, as theologian Alasdair Maclntyre asserts: 'Christianity would collapse without a working sense of $\sin .90$ 
Karl Menninger maintains, 'The clergyman [sic] cannot minimize sin and maintain his proper role in our culture. ${ }^{91}$ Without an understanding of sin, one cannot fully grasp the concepts of grace and mercy, let alone justice and restoration.

This then is the dilemma: in the face of widespread changes in meaning, can the word 'sin' really still be used, given that the concept remains so crucial? Since we cannot wipe the slate clean, how do we cope with its residual cultural usage, which as we have seen is often far from helpful?

\section{Some pointers for change}

In conclusion, then, what pointers for the rehabilitation of sin-talk can we draw from our survey of its use (and avoidance) in contemporary culture?

Francis Spufford, with whom we began, offers one route. He works around the difficulties of the word 'sin' by appealing instead to the 'common ground' of human experience. Speaking about 'the HPtFTu', Spufford suggests that 'almost everyone recognises this as one of the truths about themselves. ${ }^{\prime 2}$ Spufford's example illustrates one way of recognising that religious language, like all jargon, only communicates to the initiated. Since we live in an uninitiated society, creative communication is necessary. As Rowan Williams has suggested, 'The most effective depictions of God and grace and Christ these days are going to be sideways on and a bit different. ${ }^{193}$ Spufford's phrase is nothing if not 'sideways' and 'a bit different'.

The other route, of course, is to recover the word 'sin' itself. If, as Paul Tillich claims, 'There is a mysterious fact about the great words of our religious tradition. They cannot be replaced ... There are no substitutes for words like "sin" and "grace", 94 then this must be the challenge. It does, however, require a massive degree of re-education, both inside the Church and beyond. Perhaps an important first step is to begin with concrete biblical images as opposed to abstract words.

Picture language such as 'stain', 'trespass', 'burden' and 'bondage', for example, may resonate much more with human experience (which is why the Bible is so full of it). Care must be taken, however, with metaphors that potentially convey the wrong image. 'Debt' and 'disobedience', for example, are grounded in sound biblical concepts, but, without that background, immediately conjure up images of a demanding, autocratic God, which could be counter-productive. Pope Francis uses what might be one of the more appropriate metaphors for 
our generation, describing the Church as a field hospital and stating that 'Sin is a wound. It needs to be treated, healed. ${ }^{\prime 95}$

Whatever happened to sin? We have seen that 'sin', with its sense of personal responsibility, has slipped from our contemporary mindset, leaving behind only ironic and trivial usages, and the term 'evil' as the remaining category by which to diagnose society's malaise. Our challenge is to recover both the concept and an appropriate language to articulate it. Recognising that the residual usage of the s-word includes echoes of its former, fuller meaning is one place to start.

\section{Appendix}

Systematic trawl through database Newsstand UK of entries for 16-day period, 2-17 March 2015, http://search.proquest.com/news (accessed 16-24/03/15)

\section{Entries for the word 'sin'}

Total entries

Duplicated articles

Word used in foreign language, or name Working total

Contemporary use of term

Sin bin - Rugby, ice-hockey

Sin bin - general

Sin stock - investments in tobacco, defence etc.

Sin taxes/levy - tax on alcohol, tobacco etc.

Media references
764

207

30

527

284

267

9

4

4

60
Sins of fathers/parents - ref to film Run All Night

Seven Deadly Sins-TV series

Book titles - 14th Deadly Sin

- 2nd Deadly Sin

- The Sin Eater's Daughter

Song lyrics - 'Guilty as Sin'

- 'Holy Water'

- 'Devil Pray'

- 'Sins of St Catherine'

23

23

5

1

1

2

1

Crossword clues 
Figures of speech

Use of word as provoking disapproval

Use of word for ironic/mild wrongdoing

Cardinal sin

Sins of omission

Covering a multitude of sins

Sins of fathers - general

6

Seven deadly sins - general 6

Miserable as sin 5

For my sins 3

Guilty as $\sin 3$

Living in $\sin \quad 2$

Valley of $\sin \quad 1$

Atoning for sins 1

Be sure your sins will find you out $\quad 1$

Love the sinner, hate the sin 1

Religious use

Articles or letters in local papers $\quad 18$

Christian Science Monitor $\quad 5$

Notices of church services 2

Use as serious issue

Abandoning elderly

9

Racism

6

Debt and finance $\quad 5$

Murder/violence 2

Gay

Religious education

Envy

Selfishness

Pornography

Use in other contexts

Varied historical references 9

Islam 9

Hinduism 1 
Entries for word 'evil'

Total entries

861

(Duplicated articles

54)

Working total

805

Crime

Murder (murder of 8-year-old Ayesha Ali, by mother and lesbian lover) 43

Child abuse

Attacks

Sex crime/rape

Other

Islam/terrorists (trial of Jihadi John)

Serious

Nazism

Condemnation of gays

Drugs

Political right/UKIP

Tobacco

Communism

Russia post-Communism

Dog poisoning (at Crufts)

China power and oppression

4

Crowd taunt suicidal man

4

Cruel Tweets

4

'Possessed' child

4

Colonialism

3

Climate change

2

Tax avoidance

2

Chemical weapons Syria

2

North Korean regime

2

Racism

2

Political hypocrisy

Catholicism

Misused Third World aid

Illiteracy and innumeracy

Other 
Hilary Brand

Ironic

Tories

Mourinho

Capitalism/profit motive 3

FiFA

Rupert Murdoch 2

Feminists 2

Predatory men 2

State 2

Scottish Parliament conspiracy 2

Fossil fuels 1

UKIP 1

Tony Blair $\quad 1$

British Armed Forces 1

$\begin{array}{ll}\text { Other } & 10\end{array}$

Trivial $\quad 39$

Sugar $\quad 5$

Motorists as seen by cyclists 2

Culinary-calorific 2

Alcoho I 2

Spin doctor 'evil genius'

Fashion industry 1

Baby formula milk 1

Large conglomerates 1

Eastern Europeans Eurovision 1

Chocolate 1

Other $\quad 22$

Drama: film, TV, theatre 232

$\begin{array}{ll}\text { Novels } & 37\end{array}$

$\begin{array}{ll}\text { Computer games } & 18\end{array}$

$\begin{array}{ll}\text { Historical } & 20\end{array}$

Superstition/evil spirits (Friday 13th, eclipse) 33 
Religious

National papers opinion

Figures of speech

Necessary evil

Hear, see, speak no evil

Lesser/greater of evils

Putting off evil day

Give the evil eye

Love of money ...

Root of all evil (other)

Triumph of good over evil

Other

Entries for 'sin' and 'evil' together

Total references

Number of which are Irish

Serious references

Evil tobacco etc. - sin stocks

Slave railroad

Mary MacAleese on Catholic reform

Irish memoir

Boko Haram

Trivial

Evil eye-patch - Seven Deadly Sins

Evil bounce - sin bin (rugby)

Evil villain - Sin City

Figures of speech

Putting off evil day - sins of omission

Religious use 


\section{Notes}

1. Paul Flowers, Newsnight, 25 March 2014, www.bbc.co.uk/news/uk-26734513 (accessed 07/07/14).

2. Vallely 2014, p. 7.

3. Francis Spufford 2012, p. 28.

4. Spufford 2012, p. 24.

5. See the Appendix for a full analysis. Source: www.newsstand.co.uk (accessed 16-18/03/15).

6. Zoe Williams, 'Opinion: Bring on the sin bin for MPs', Guardian, 2 March 2015.

7. 'Cadbury is being led to disaster', Birmingham Mail, 5 March 2015.

8. Janine Thomas, 'Want sweet success in the kitchen?', Daily Mail, 10 March 2015.

9. 'Top searched destinations of 2015', Manchester Evening News, 14 March 2015.

10. Jeff Prestridge, 'Ofgem's "ban" is in a league of its own', Mail on Sunday, 8 March 2015.

11. Brian Appleyard, 'If the shoe fits', Sunday Times, 15 March 2015.

12. Gillie Sutherland, Express \& Echo (Exeter), 9 March 2015.

13. Anthony Cummins, 'The Critics: Fiction', Observer, 8 March 2015.

14. Spufford 2012, p. 24.

15. Both these examples were artificially swollen by new media releases: the first the film Run All Night, where a press release must have fed the term into every review; the second a TV series, The Seven Deadly Sins, exploring how animals present behaviours in the same 'sinful' categories.

16. www.collinsdictionary.com.

17. Katie Glass, 'Glass House: Help, I'm a serial flat-sharer', Sunday Times, 8 March 2015.

18. 'It's spring and the Sun is out', Sun, 6 March 2015.

19. Bishop Kevin Doran, quoted in 'Gay People are not necessarily parents', Kildare Nationalist, 9 March 2015.

20. Christopher Woodhouse, 'Preacher claims 50 shades could cause sex crimes', Belfast Telegraph, 8 March 2015.

21. 'Christian nursery worker rejected yoga', Daily Telegraph, 4 March 2015.

22. 'Quote of the week', Mail on Sunday, 8 March 2015.

23. Joe Hinton, 'Dozens of UK Jihadis dying on front line', Daily Star, 8 March 2015.

24. 'Boko Haram swears allegiance to Isil', Daily Telegraph, 7 March 2015.

25. Boyd Tonkin (speaking of Jeremy Clarkson's dismissal from Top Gear), 'Aging, middle-class, right-wing', The Independent, 14 March 2015.

26. For more detail, again see Appendix.

27. Figure swollen by reports on 'Jihadi John'.

28. Of these, six appeared in Irish papers, a higher incidence noticeable in the separate usages as well.

29. Of the total number of references, the highest other category was fiction with 287 entries, followed by crime with 105 . Twenty-two referred to the societal evils of various substances: drugs, tobacco, alcohol, sugar, baby formula milk (though only one mention of the evils of money). Apart from terrorists and criminals, the only individuals mentioned as evil (all ironically) were well-known institutional figures. Most others were figures of speech or ironic and trivial mentions. 
30. Guardian and Daily Mail, 16 March 2015.

31. Mark Kermode,' Film reviews', Observer, 18 March 2015.

32. A Touch of $\operatorname{Sin}, 2013$.

33. Jonathan Landreth, 'How China made sure there'd be no touch of sin at the Oscars', 1 March 2014, www.asiasociety.org (accessed 10/05/15).

34. Tania Branigan, 'China must end silence on injustice warns Jia Zhangke', Guardian, 24 April 2013.

35. Sin City: A Dame to Kill For, 2014.

36. Umberto Eco, quoted in Kelton Cobb, Blackwell Guide to Theology and Popular Culture, Oxford: Wiley-Blackwell, 2005, p. 66.

37. Baudrillard 1981, p. 1.

38. Baudrillard 1981, p. 2.

39. http://www.sinner.eu/en/?gclid=CMLHpu-jrcUCFWgOwwodFJkARQ (accessed 06/05/15).

40. www.sinfulcolors.com (accessed 06/05/15).

41. http://www.boots.com/en/So-Sinful-body-spray-75ml_1020310 (accessed 06/ 05/15).

42. http://www.swingpatrol.co.uk/class/sin-city-blues (accessed 06/05/15).

43. Michael Gadd, 'Sexy Silhouettes and Lashings of Lace', MailOnline, 21 December 2014 (accessed 12/10/14).

44. http://www.gamespot.com/reviews/divinity-original-sin-review/1900-6415819/.

45. Mike Anderoesz, 'Games blog', GuardianOnline, 13 May 2010 (accessed 19/10/14).

46. http://www.marketingmagazine.co.uk/article/168845/magnum-repackage-sevendeadly-sins (accessed 06/05/15).

47. Item bought in January 2015.

48. Slimming World, on www.slimmingworldsurvival.com.

49. Mark Jackson, 'Having her cake and eating it', MailOnline, 24 November 2014 (accessed 03/12/14).

50. Sebastian Shakespeare, 'So Camilla, what's cooking?', Daily Mail, 23 October 2014 (accessed 19/11/14).

51. Johnston 2014.

52. Ricoeur 1965, pp. 93, 95 and 96.

53. Ricoeur 1967, p. 29.

54. Menninger 1973, p. 36.

55. http://www.catholiceducation.org/en/marriage-and-family/sexuality/ masturbation.html (accessed 15/05/15).

56. Menninger 1973, p. 36.

57. Peep Show, 2008, series 5, episode 2, 'Jeremy's broke'.

58. It should be noted that this breaks a different taboo from male masturbation, more linked to issues of impurity than the concept of natural law.

59. Gavin and Stacey, 2008, series 2, episodes 4 and 5.

60. Over 10,500 people in the UK used a sex addiction online recovery programme in the 18 months from January 2014, reported by Martin Daubney, 'The lust generation', Sunday Times Magazine, 7 June 2015.

61. Portmann 2007, p. xvii. 
62. Calvary, 2014.

63. The Commission to Inquire into Child Abuse (May 2009), reported by David Dwan, 'Book Review: Occasions of Sin: Sex and Society in Modern Ireland', Guardian, 12 September 2009 (accessed 19/10/14).

64. Sex and the Church, 2015, episode 3.

65. Philomena, 2013.

66. Catholic News Service (11/04/14), 'Pope apologises for clerical sexual abuse, promises tougher sanctions', 11 April 2014, www.catholicnews.com/data/stories/ cns/1401505.htm (accessed 06/07/15).

67. David Batty, 'Banksy wades into Catholic Church abuse scandal with new sculpture', Guardian, 15 December 2011, www.theguardian.com/gnm-archive (accessed 19/10/14). (Cardinal Sin is in the Walker Gallery, Liverpool.)

68. Matt Roper, 'Pope told divorced woman "living in sin" she could receive Holy Communion', Daily Mail, 12 March 2015, http://www.dailymail.co.uk/news/ (accessed 19/03/15).

69. Madonna Ciccone, Martin Kierszenbaum, Natalia Noemi, 'Holy Water', Rebel Heart album, Warner/Chappell Music Inc., 2015.

70. Hozier, 'Take Me to Church', Columbia, Ruby-Works, Universal-Island, 2013.

71. Andy Greene, 'Behind Hozier's Unlikely Rise', Rolling Stone, 29 January 2015, New York: Wenner Media LLC, http://www.rollingstone.com/music/features/behindhoziers-unlikely-rise (accessed 12/06/15).

72. James Shepherd, 'Q \& A: Hozier on Gay Rights, Sexuality and Good Hair', New York Magazine, 11 March 2014, http://nymag.com/thecut/2014/03/qa-hozier-on-gayrights-sex-good-hair (accessed 12/06/15).

73. Micah Murray, 'Why I can't say love the sin, hate the sinner any more', 31 December 2013, www.huffingtonpost.co/micah-j-murray (accessed 07/07/14).

74. Daily Telegraph, 'Christian nursery worker rejected yoga', 4 March 2015, www.newsstand.co.uk (accessed 16/03/15). The ruling was later overturned by an employment tribunal: Maria Woolf and Nicholas Hellen, 'Victory for sacked Christian nanny', Sunday Times, 7 June 2015.

75. 'My brother was told God didn't love him', MailOnline, 21 October 2014, www.dailymail.co.uk (accessed 16/12/14).

76. 'Moment Orange is New Black actress unleashed expletive-filled rant', MailOnline, 4 November 2014, www.dailymail.co.uk (accessed 16/12/14).

77. Christopher Bunn, 'The radical evangelical whose support for gay marriage is rocking his field', 23 January 2013, www.theguardian.com/commentisfree (accessed 09/07/15).

78. David Willey, 'Pope Francis has said gay people should not be marginalised', BBC News, 29 July 2013, www.bbc.co.uk/news/world-europe-23489702 (accessed 09/07/15).

79. Jenn Selby, 'Archbishop of Canterbury Justin Welby discusses gay rights with Muslim students', The Independent, 24 February 2015, www.Independent.co.uk (accessed 09/07/15).

80. Lesbian, Gay, Bisexual, Transgender.

81. Cheng 2012, pp. 3-4. 
82. Cheng 2012, pp. 5 and 6.

83. Maureen Ryan, interview with Vince Gilligan, 8 August 2012, www.huffington post.com (accessed 07/07/15).

84. Kyle Roberts, 'Breaking Bad: Why society still needs "sin language"', 16 August 2012, www.patheos.com/blogs (accessed 07/07/15).

85. Vince Gilligan, in Ryan 2012.

86. Vince Gilligan, interview in New York Times, cited by Roberts 2012.

87. Hornby 2001, p. 193.

88. Hornby 2001, p. 181.

89. Dawkins 2006, p. 285.

90. Maclntyre 2007, quoted by Portmann 2007, p. 27.

91. Karl Menninger 1973, p. 198.

92. Spufford 2012, p. 27.

93. Rowan Williams, quoted in Tate 2010, p. 50.

94. Tillich 1955.

95. Ricoeur 1965, p. 23.

\section{Bibliography}

Anderson, G. 2009. Sin: A History. New Haven and London: Yale University Press.

Baudrillard, J. 1981. Trans. Glaser, S. F. 1994. Simulacra and Simulation. Ann Arbor, MI: University of Michigan Press. Available at: http://www.bconradwilliams.com/ files/7313/9690/1991/Baudrillard-Jean-Simulacra-And-Simulation2.pdf (accessed 09/08/16).

Cheng, P. S. 2012. From Sin to Amazing Grace: Discovering the Queer Christ. New York: Seabury Books.

Connolly, H. 2002. Sin. New Century Theology. London and New York: Continuum.

Dawkins, R. 2006. The God Delusion. London: Bantam Press.

Eagleton, T. 2010. On Evil. New Haven and London: Yale University Press.

Fredriksen, P. 2012. Sin: The Early History of an Idea. Princeton, NJ and Oxford: Princeton University Press.

Hornby, N. 2001. How to be Good. London: Penguin.

Johnston, A. 2014. 'Jacques Lacan', The Stanford Encyclopedia of Philosophy, http:// plato.stanford.edu/archives/sum2014/entries/lacan (accessed 12/05/15).

Jopling, D., Pippin, T. and Schliefer, R. (eds). 2001. The Post-Modern Bible Reader. Oxford: Blackwell.

Kelsey, D. H. 1993. 'Whatever Happened to the Doctrine of Sin?', Theology Today 50.

Mahn, J. A. 2011. Fortunate Fallibility: Kierkegaard and the Power of Sin. Oxford and New York: Oxford University Press.

Menninger, K. 1973. Whatever Became of Sin? New York: Hawthorn Books.

Nelson, D. R. 2011. Sin: A Guide for the Perplexed. London: T \& T Clark.

Plantinga, C. Jr. 1995. Not the Way It's Supposed to Be: A Breviary of Sin. Grand Rapids, MI: Eerdmans.

Portmann, J. 2007. A History of Sin: Its Evolution to Today and Beyond. Lanham, MD: Rowman \& Littlefield. 
Ricoeur, P. 1965. Fallible Man, trans. Kelbley, C. New York: Fordham University Press (1960, L'Homme Faillible, Paris: Editions Montaigne).

Ricoeur, P. 1967. Trans. Buchanan, E. 1969. The Symbolism of Evil. New York: Beacon Press. Spufford, F. 2012. Unapologetic: Why, Despite Everything, Christianity Can Still Make Surprising Emotional Sense. London: Faber and Faber.

Tate, A. 2010. Contemporary Fiction and Christianity. London and New York: Continuum. Tillich, P. 1949 (trans. 1955). The Shaking of the Foundations, http://media.sabda.org/ alkitab-2/Religion-Online.org\%20Books/Tillich,\%20Paul\%20-\%20The\%20Shaking \%20of\%20the\%20Foundations.pdf.

Vallely, P. 2014. 'Living out of Sin', Third Way (May).

\section{Film, TV and Video}

Breaking Bad. 2008-13. Creator: Vince Gilligan [TV] USA: AMC.

Calvary. 2014. Director: John Michael McDonagh [Film] Ireland and UK: Entertainment One.

Gavin and Stacey. 2007-10. Creators: Ruth Jones and James Corden [TV] UK: BBC1. Magdalen Sisters, 2002, Director: Peter Mullan [Film] Ireland and UK: Magna Pacific. Peep Show. 2003-15. Creators: Jesse Armstrong and Sam Bain [TV] UK: Channel 4. Philomena. 2013. Director: Stephen Frears [Film] UK and USA: Pathe.

Sex and the Church. 2015. Writer and presenter: Diarmaid MacCulloch [TV] UK: BBC2. Sin City: A Dame to Die For. 2014. Directors: Robert Rodriguez and Frank Miller [Film] USA: Dimension Films.

There's Something about Mary. 1998. Directors: Peter and Robert Farrelly [Film] USA: 20th Century Fox.

A Touch of Sin. 2013. Director: Jia Zhangke [Film] China: Arrow Films. 